

\title{
DONATING BEHAVIOUR AND ATTITUDES: AN EXPLORATORY STUDY OF THE DIFFERENCES IN AGE COHORTS
}

\author{
by \\ Mary K. Foster \\ Agnes G. Meinhard
}

Given the decrease in government support of the voluntary sector, non-profit organizations will be increasing their fund-raising activity. This exploratory study investigates the differences in donating behaviour and attitudes among younger (18-34) and older (35+) Ontarians.

\section{Introduction}

Voluntary organizations in Ontario traditionally have operated with significant support from government funding programs. However, with federal and provincial deficits growing out of control, governments have decided drastic action is required. The federal government is reducing transfer payments to Ontario for health, education and welfare by $\$ 3$ billion for 1996-98. At the same time, Ontarians have elected Progressive Conservatives to the provincial legislature with a mandate to implement their "Common Sense Revolution", which promises to reel in the deficit and provide tax relief. The Tories have wasted no time in slashing $\$ 8$ billion dollars from the social programs budget effectively reducing funding for welfare by $22 \%$. This is in addition to the reduction in the federal government's transfer payments which from 1990-91 to 1995-6 have cost Ontarians \$12.4 billion (Baker, 1996). These steps are not a short term fiscal adjustment, but rather a long-term and fundamental change in direction. Governments can no longer underwrite the breadth and depth of social services traditionally a birthright of Canadians because taxpayers are no longer able to pay for them. As a result, voluntary organizations need to generate revenue from private donations to replace this lost government funding. Since these government cuts are across the board, all voluntary organizations will be turning elsewhere for funding. They will be thrust into a competitive environment, not only with other voluntary organizations, but also with public institutions, such as hosptitals and universities.

Previous research has shown that volunteer participation peaks in the age range 35 to 55 (Smith, 1994). Because this segment of the population has always been a target for donating to charities, the established non-profit organizations have well-developed fund-raising programs aimed at this audience. In addition, in the current fiscal environment, it seems certain that the demands for donations will increase. In order to have a sustainable donor base, non-profit organizations will have to focus on socializing the new generation into the habit of commitment to charities. In Canada there has been little research that has focused on the differences between age cohorts in their attitudes toward charities and their donating behaviour. The last Statistics Canada study on the voluntary sector was conducted in 1987. Campbell (1994) indicates that the charities' data do not provide a valid breakdown between corporate and individual receipts which makes it difficult to do reliable subgroup analysis. The purpose of this paper is to investigate donating behaviour, reaction to alternative fund-raising appeal techniques and attitudes toward charities by age. 


\section{Background}

What do organizations have to do in order to market their cause and generate revenue to support their programs? Traditional marketing textbooks are very clear about the steps an organization should follow in designing an effective communication program. First, the organization must identify its target audience, determine its communication objectives, design the message, select the communication channels, allocate the total promotion budget, decide on the promotion mix, measure the promotion's results and manage and coordinate the total marketing communication process (Dickson, 1994, Kotler \& Turner, 1995). For not-for-profit organizations, the key is to begin with a donor analysis to define the most relevant target markets and develop strategies to best reach and influence these segments (Rothschild, 1987).

As mentioned previously, the typical target for charities is the 35 to 55 year old cohort (Smith, 1994). This group makes up the bulk of the baby boomers in Canada and has an attitudinal profile that is different from those born later (Foot, 1996). Today the baby boomers are middle-aged and established in their families, their communities and their jobs, the very characteristics that Smith (1994) identified as being the pre-eminent indicators of charitable participation. Their charitable giving and volunteering is an extension on their idealistic and procactive youth. Baby boomers could afford to be idealistic in youth as they were virtually guaranteed jobs when they chose to join the economic mainstream, especially those at the front of the boom and those with higher education. On the other hand, Generation X, those born at the back end of the baby boom have had greater difficulties in finding a job and are beginning their careers at a later age. Consequently, their average income is $10 \%$ less than their parent's at the same age. These difficulties have led to an attitude of distrust for large institutions whether they be in the private or public sector. Because the Generation Xers have had difficulty getting established, they have neither the time nor resources to see beyond their own immediate needs (Foot, 1996).

These cohort differences underline the importance for voluntary organizations of understanding the nature of the upcoming generation and not simply using the same strategies that have worked for the baby boomer generation. While marketers in the for-profit sector are developing age-specific strategies, there is little evidence that the non-profit sector is systematically following the same course. It may be a prudent strategy for the voluntary sector to pay more attention to age cohorts by identifying any differences which in fact exist; and to understand the impact of these differences on attitudes and behaviour. This information could ultimately lead to more effective communication strategies with better outcomes.

\section{Method}

A sample of 364 current donors was surveyed using a telephone interview in October and November 1996. Respondents were chosen by random dialling of households in Metro Toronto, York Region, Durham Region and Peel Region. Only those 18 years of age or over who had made a financial donation or a contribution-in-kind to a charity in the last twelve months qualified to participate. Analysis of variance was used to identify the differences between two age cohorts (18 to 34 and 35 and over) in donating behaviour, fund-raising motivators and attitudes towards charities.

\section{Results}

This study examines the differences between two age cohorts with respect to: a) donating behaviour, b) response to various appeal strategies, c) response to different kinds of incentives, and d) 
attitudes towards the voluntary sector. Overall, there were consistent differences between the two age groups. The results are presented in Tables 1 to 8 . Table 1 reports average numbers of donations and average dollars donated from raw scores. Tables 2 to 8 report averages calculated from responses to a five point scale, where ordinal measurements were treated as interval data, according to accepted practice (Bogatta and Bohrenstedt, 1980; Kerlinger, 1973). We recognize that this method may distort findings, therefore we corroborated all findings by chi square analyses and found no differences in the results.

\section{Donating Behaviour}

Respondents were asked to report their donating behaviour over the past year. Table 1 presents the results. The older age group makes significantly more receipted donations than the younger group. This is a significant difference that persists even after age effects were controlled for by size of family income. Both age and income have significant main effects while the interaction was not signinficant. The total dollar donation is also significantly higher for the older group, totalling $\$ 757$ as opposed to $\$ 138$. Here too age effects persist even after controlling for income, (both variables having significant main effects), however there is also a significant interaction. The data indicate that the discrepancy between donations and age increases as income increases. One plausible explanation is that at different stages of the life cycle, individuals have different priorities for their discretionary income. High income 18 to 34 year olds choose to spend their money on different things than do high income individuals over 35 (Foot, 1996; Naisbitt \& Aburdene, 1990). Although the average donation for older people is higher as well (\$142 vs. $\$ 47$, the difference fails to reach significance. There is no difference between old and young when it comes to non-receipted donations, however the young have more non-receipted than receipted donations, whereas the opposite is true for the older group. The difficulty with the non-receipted data is that they are dependent on memory and without a definitive trigger like a tax receipt, the chances of over and underreporting increase dramatically.

Table 1

Donating Behaviour by Age

\begin{tabular}{|l|c|c|c|}
\hline Mean & $\begin{array}{c}\mathbf{1 8 - 3 4} \\
(\mathbf{n = 1 7 1})\end{array}$ & $\begin{array}{c}\mathbf{3 5}+ \\
(\mathbf{n}=\mathbf{1 6 6})\end{array}$ & $\mathbf{p}=$ \\
\hline Number of receipted donations & 2.3 & 5.4 & .0000 \\
\hline Total \$ tax-receipted donations & $\$ 138$ & $\$ 757$ & .0007 \\
\hline Average \$ tax-receipted donations & $\$ 47$ & $\$ 142$ & .1191 \\
\hline Number of non-receipted donations & 3.3 & 3.2 & .8981 \\
\hline Total \$ non-receipted donations & $\$ 62$ & $\$ 228$ & .1833 \\
\hline Average \$ non-receipted donations & $\$ 22$ & $\$ 34$ & .3963 \\
\hline
\end{tabular}




\section{Response to Appeal Strategies}

Telephone appeal. Table 2 reveals that neither group is at all likely to donate as a result of a personal approach using the telephone. This is an important finding because telemarketing has been used by the private sector as a replacement for the more expensive personal selling. These negative feelings of both age groups of donors toward telephone solicitation suggests that organizations embarking on new fund-raising campaigns engage in telemarketing at some risk of alienating their target audience. Responses to different types of callers were also measured. Older callers were less responsive to the various types of callers. For both groups, a paid caller or a board member calling are likely to decrease an already low motivation to donate, whereas being called by a user of the service or by someone known by the respondent may increase the likelihood of donating. This suggests that careful choice of the caller may be able to mitigate the general negative reaction to telephone appeals especially when directed toward the younger age group.

Mail appeal. The findings presented in Table 3 indicate that older respondents are more likely to donate if approached by mail than are younger respondents. A mail appeal with a letter signed by someone the respondents knows, or a user of the service, or one that contains facts and figures is more likely to increase donating behaviour than is having a board member or a celebrity sign the letter. For each alternative signer of the mail appeal, the likelihood of the younger group increasing its motivation to donate is significantly greater than the older group. These findings underline the importance of careful choice of both the message and the sponsor.

Table 2

Likelihood of Donating to a Telephone Appeal by Age

\begin{tabular}{|l|c|c|c|}
\hline Specifics of telephone appeal & $\begin{array}{c}\mathbf{1 8 - 3 4} \\
(\mathbf{n = 1 8 4})\end{array}$ & $\begin{array}{c}\mathbf{3 5}+ \\
(\mathbf{n}=\mathbf{1 7 6})\end{array}$ & $\mathbf{p}=$ \\
\hline Telephone appeal in general* & 1.6 & 1.6 & .7769 \\
\hline Called by paid caller & 4.0 & 4.2 & .0384 \\
\hline Called by someone you know & 2.2 & 2.6 & .0024 \\
\hline Called by board member & 3.1 & 3.4 & .0114 \\
\hline Called by user of the service & 2.7 & 3.0 & .0074 \\
\hline
\end{tabular}

* Based on a 5 point scale from not very likely to very likely to donate. For this category only, the higher the number the more likely to donate. The rest of the categories are based on a 5 point scale from much more likely to much less likely to donate and the higher the number the less likely to donate. 
Table 3

Likelihood of Donating to a Mail Appeal by Age

\begin{tabular}{|l|c|c|c|}
\hline Specifics of mail appeal & $\begin{array}{c}\mathbf{1 8 - 3 4} \\
\mathbf{( n = 1 8 4 )}\end{array}$ & $\begin{array}{c}\mathbf{3 5}+ \\
(\mathbf{n = 1 7 6})\end{array}$ & $\mathbf{p}=$ \\
\hline Mail appeal in general* & 2.2 & 2.4 & .0813 \\
\hline Letter signed by someone you know & 2.4 & 2.7 & .0124 \\
\hline Letter signed by a board member & 3.0 & 3.3 & .0036 \\
\hline Letter signed by a celebrity & 3.0 & 3.4 & .0001 \\
\hline Letter signed by a user of the service & 2.6 & 2.9 & .0127 \\
\hline Letter includes facts and figures & 2.7 & 3.0 & .0029 \\
\hline
\end{tabular}

* Based on a 5 point scale from not very likely to very likely to donate. For this category only, the higher the number the more likely to donate. The rest of the categories are based on a 5 point scale from much more likely to much less likely to donate and the higher the number the less likely to donate.

Personal visit . The likelihood of donating as a result of a personal visit is higher than for mail and much higher than for a telephone appeal. (See Table 4.) Other types of appeals including bake sales, community special projects and mall displays had the highest level of likelihood of donating compared to all other personal types of communication. The younger age group is more likely than the older age group to respond to a personal visit in general, and significantly more likely to respond positively to visits by board members and by someone they know. Overall, being visited by someone the respondent knows or by a user of the service is more likely to increase the propensity to donate than is a visit from a stranger or a board member.

Table 4

Likelihood of Donating to a Personal Visit Appeal by Age

\begin{tabular}{|l|c|c|c|}
\hline Specifics of personal visit appeal & $\begin{array}{c}\mathbf{1 8 - 3 4} \\
\mathbf{( n = 1 8 4})\end{array}$ & $\begin{array}{c}\mathbf{3 5}+ \\
(\mathbf{n}=\mathbf{1 7 6})\end{array}$ & $\mathbf{p}=$ \\
\hline Personal visit appeal in general* & 3.1 & 2.9 & .0566 \\
\hline Visited by a stranger & 3.3 & 3.5 & .0987 \\
\hline Visited by someone you know & 2.0 & 2.2 & .0905 \\
\hline Visited by board member & 2.9 & 3.3 & .0012 \\
\hline Visited by user of the service & 2.3 & 2.7 & .0004 \\
\hline Other type of appeal* & 3.6 & 3.3 & .0439 \\
\hline
\end{tabular}


* Based on a 5 point scale from not very likely to very likely to donate. For these categories only, the higher the number the more likely to donate. The rest of the categories are based on a 5 point scale from much more likely to much less likely to donate and the higher the number the less likely to donate.

Media appeals. While the previous tables focus on personal appeals, Table 5 presents the results of impersonal appeals. In general, they are less effective than mail or a personal visit, but more effective than telephone appeals especially in the younger age group. In the younger age group newspaper and radio are significantly more effective than in the older age group, as are the use of celebrities and users of the service as spokespersons, and including facts and figures and illustrations in the presentation. Overall, the use of illustrations and users of the service as spokespersons is more likely to achieve a positive outcome, than are celebrities and including facts and figures.

Table 5

Likelihood of Donating to a Media Appeal by Age

\begin{tabular}{|l|c|c|c|}
\hline Specifics of media appeal & $\begin{array}{c}\mathbf{1 8 - 3 4} \\
\mathbf{( n = 1 8 4 )}\end{array}$ & $\begin{array}{c}\mathbf{3 5}+ \\
(\mathbf{n = 1 7 6})\end{array}$ & $\mathbf{p}=$ \\
\hline Newspaper appeal in general* & 2.0 & 1.7 & .0170 \\
\hline Radio appeal in general* & 2.0 & 1.6 & .0009 \\
\hline Television appeal in general* & 2.3 & 2.0 & .0575 \\
\hline Celebrity spokesperson & 3.1 & 3.4 & .0015 \\
\hline User of service spokesperson & 2.5 & 2.9 & .0030 \\
\hline Includes facts and figures & 2.7 & 3.2 & .0000 \\
\hline Includes illustration & 2.6 & 3.0 & .0013 \\
\hline
\end{tabular}

* Based on a 5 point scale from not very likely to very likely to donate. For these categories only, the higher the number the more likely to donate. The rest of the categories are based on a 5 point scale from much more likely to much less likely to donate and the higher the number the less likely to donate.

\section{Incentives}

Method of payment. One of the basic precepts of product offerings is to remove obstacles to purchase. By offering different payment methods, non-profit organizations are removing an objection to donating. Table 6 indicated that the younger age group is significantly more likely than the older age group to donate if cash is accepted or if an installment plan is offered. The older age group is significantly more likely to donate if payment by cheque is an option. The propensity to donate is the same for both age groups when credit card or payroll deduction are options. The implication is that charities must offer a range of payment options if they are to satisfy the preferences of various market segments. 
Table 6

Likelihood of Method of Payment Influencing Donating by Age*

\begin{tabular}{|l|c|c|c|}
\hline Method of Payment & $\begin{array}{c}\mathbf{1 8 - 3 4} \\
\mathbf{( n = 1 8 4 )}\end{array}$ & $\begin{array}{c}\mathbf{3 5}+ \\
\mathbf{( n = 1 7 6 )}\end{array}$ & $\mathbf{p =}$ \\
\hline Cash & 3.0 & 3.3 & .0366 \\
\hline Cheque & 2.7 & 2.5 & .0320 \\
\hline Credit card & 3.6 & 3.7 & .5182 \\
\hline Payroll deduction & 3.5 & 3.5 & .8987 \\
\hline Installment & 3.5 & 3.8 & .0090 \\
\hline
\end{tabular}

* The categories are based on a 5 point scale from much more likely to much less likely to donate and the higher the number the less likely to donate.

Other incentives. Some non-profit organizations offer tangible returns for a donation beyond the typical tax receipt and the expected thank-you. As Table 7 suggests the return to the donor is more likely to have an influence on the younger age group than the older age group. The 18-34 cohort is significantly more likely to donate if they receive a product in return or have the opportunity to attend a special event.

\section{Table 7}

\section{Likelihood of Other Incentives Influencing Donating by Age*}

\begin{tabular}{|l|c|c|c|}
\hline Incentive & $\begin{array}{c}\mathbf{1 8 - 3 4} \\
\mathbf{( n = 1 8 4})\end{array}$ & $\begin{array}{c}\mathbf{3 5}+ \\
(\mathbf{n}=\mathbf{1 7 6})\end{array}$ & $\mathbf{p}=$ \\
\hline Product & 2.6 & 3.2 & .0000 \\
\hline Special event & 2.5 & 3.0 & .0001 \\
\hline Tax receipt & 2.3 & 2.2 & .1500 \\
\hline A thank you & 2.6 & 2.8 & .1181 \\
\hline
\end{tabular}

* The categories are based on a 5 point scale from much more likely to much less likely to donate and the higher the number the less likely to donate.

\section{Attitudes Towards Charities}

Table 8 presents the results from a series of attitudinal statements about charities and government 
involvement in social services. Respondents strongly agree that fund raising is important for charities, that there should be cooperation between charities, community groups and all levels of government; and disagree that the government is on the right track reducing its support of social services. There are no significant differences between age groups except for the two following items. The older age group is significantly more likely to agree with the statements that "charities should tighten their operations to get more for their money", and that "constant soliciting irritates me". For these two items, the main effects by age are not wiped out by education and there is no interaction between age and education. The implication is the younger age group is not necessarily giving less to charity because they feel differently about charities than does the older age group. It may be that because of their experience in the era in which they have grown up that they have not been socialized into donating (Foot, 1996).

\section{Table 8}

\section{Level of Agreement with Statements about Charities by Age*}

\begin{tabular}{|c|c|c|c|}
\hline & $\begin{array}{c}18-34 \\
(n=184)\end{array}$ & $\begin{array}{c}35+ \\
(n=176)\end{array}$ & $p=$ \\
\hline $\begin{array}{l}\text { Charities that do not give tax receipts do not seem } \\
\text { legitimate to me. }\end{array}$ & 3.4 & 3.5 & .2591 \\
\hline $\begin{array}{l}\text { I understand how important it is for charities to be } \\
\text { constantly fund-raising. }\end{array}$ & 4.1 & 4.0 & .2670 \\
\hline $\begin{array}{l}\text { The government is on the right track reducing its support } \\
\text { of social services. }\end{array}$ & 2.4 & 2.5 & .4354 \\
\hline $\begin{array}{l}\text { Charities should amalgamate to be more efficient at fund- } \\
\text { raising. }\end{array}$ & 3.5 & 3.4 & .6724 \\
\hline Most charities are scams. & 2.6 & 2.4 & .2389 \\
\hline $\begin{array}{l}\text { There should cooperation between charities, community } \\
\text { groups and all levels of government to provide services. }\end{array}$ & 3.9 & 4.0 & .7554 \\
\hline $\begin{array}{l}\text { Telephone calls from charities always come at the wrong } \\
\text { time. }\end{array}$ & 3.5 & 3.7 & .1445 \\
\hline $\begin{array}{l}\text { It is a key role of high schools to encourage community } \\
\text { service by young people by making it part of the } \\
\text { curriculum. }\end{array}$ & 3.5 & 3.6 & .6993 \\
\hline $\begin{array}{l}\text { Private donations can never replace government support } \\
\text { of charities. }\end{array}$ & 3.3 & 3.4 & .6503 \\
\hline $\begin{array}{l}\text { Charities should tighten their operations to get more for } \\
\text { their money. }\end{array}$ & 3.3 & 3.7 & .0008 \\
\hline Constant soliciting by charities irritates me. & 3.3 & 3.8 & .0008 \\
\hline $\begin{array}{l}\text { The government has a moral obligation to support social } \\
\text { services to the fullest extent. }\end{array}$ & 3.6 & 3.6 & .8771 \\
\hline
\end{tabular}


* These categories are based on a 5 point scale from strongly disagree to strongly agree and the higher the number, the more likely is the respondent to agree with the statement.

\section{Discussion}

The limitation of this study is that it has not considered the role of the product characteristics; that is the worthiness of a particular cause in motivating donating behaviour. Notwithstanding these shortcomings, the data provide guidance for non-profit organizations without well-developed fund-raising programs and direction for those wanting to develop sustainable donor loyalty in the younger age groups.

Not every organization displays the same level of marketing expertise, often because of lack of resources. Some well-established not-for profit organizations use sophisticated geodemographic systems to tailor the type of appeal to specific destination postal codes. Others may purchase mailing lists from other similar organizations or from direct mail houses who can supply specialized lists of specific types of potential donors (Kotler \& Andreasen, 1996). The challenge for VSSOs is that they have few human or fiscal resources to allocate to these endeavours nor do they have the internal expertise to guide the process (Bloom \& Novelli, 1981; Drucker, 1989; Rothschild, 1979). Traditionally, not-for-profit organizations have not operated within a marketing framework. Wilson (1984) suggests that staff attitudes within voluntary organizations play a major role in negative feelings about marketing. Professionals working in this sector have been trained in antipathy toward commerce because of its association with a "hard sell". From a fundraising perspective, the voluntary sector appears more comfortable with a product orientation; that is, if the cause is good, people will give.

As McLeish (1995) points out, the strategy of letting the initiative of donors drive fund-raising is not viable in the current environment. The growth in the number of non-profit organizations has increased competition for the same dollars. Donors feel over-solicited as these organizations compete for the same audiences. No longer can organizations count on a loyal donor base as sustained loyalty to specific causes is eroded through competition from other equally worthy causes. In addition, the voluntary sector has to approach the public with sophisticated communication programs because information technology has raised the expectations of the public about what is possible. Finally, donors expect to be involved in the disposition of revenues and are also more selective in which causes they support (Kotler \& Andreasen, 1996; McLeish, 1995; Rice, 1992).

As the results indicate the different age groups have different reactions to each appeal technique. Advertising is a very public mode of communication which confers an aura of legitimacy on the product presented or the organization sponsoring the communication (Kotler \& Turner, 1995). The disadvantage of this type of communication is that it is impersonal and the audience does not feel obligated to respond. Otteson (1977) suggests that this type of vehicle is useful for developing awareness which is an essential step in initiating donating behaviour. The younger age group may have been more predisposed to the impersonal type of communication because they do not have the same level of awareness as the older group and appreciated this type of approach because of its information value.

Direct marketing which includes direct mail and telemarketing can be personalized to a specific individual and can include a customized appeal (Kotler \& Turner, 1995). While telemarketing is relatively low cost, it is a personal approach which does provide an opportunity to respond immediately to target audience concerns (Novelli, 1981). Despite its benefits, the data are clear that telephone solicitation is viewed with disdain across all age groups. However, it appears that the negative impact can be somewhat mitigated by the careful choice of caller. 
Personal selling through visits is the most expensive contact tool even when volunteers are used because of the costs of recruiting, training and motivating them. The benefit of a personal appeal is that it makes the buyer feel obligated to respond (Kotler \& Andreasen, 1996). As with telemarketing, the findings suggest that in order for the campaign to be successful, attention must be paid to who actually makes the visit.

Spokespersons particularly celebrities are often used by voluntary organizations because they may be respected and credible experts in the field or are viewed as trustworthy (Sternthal et al., 1978; Craig \& McCann, 1977). The choice of the right celebrity is critical because of the transfer of the spokesperson's qualities to the organization (Rein et al., 1987). However, there can be difficulties in using spokespersons as they can be distracting and undermine attention to the message and reduce learning (Ogilvy \& Raphaelson, 1982). There is also evidence to suggest that audiences are becoming bored with celebrity spokespeople (Lipman, 1990). This may explain the lower ratings for celebrities compared to users of the service. The general public is somewhat jaded by celebrity spokespersons given recent scandals especially in the sporting arena.

\section{Conclusion}

Given the current fiscal climate, having a sustainable donor base will be even more important to voluntary organizations than it has been in the past. The findings suggest that the younger generation has the attitudes in place to eventually give as generously as the older generation currently gives. A key finding is the importance of carefully choosing the spokesperson for a charity as this individual can have a decided positive or negative influence on the number of donations. Finally, voluntary organizations embarking on more formal fund-raising programs for the first time would be well advised to consider the tried and true methods of door-to-door canvassing and community special events as these were the most likely to have a positive impact on propensity to donate. Volunteers are the necessary ingredient to make these kinds of approaches successful.

\section{References}

Baker, T., Personal Communication, Toronto: Social Planning Council of Metropolitan Toronto, 1996.

Bloom P. and Novelli, W.D., "Problems and Challenges in Social Marketing," Journal of Marketing, 45(1981), 79-88.

Campbell, D.R., The First General Map of Canada's Third Sector, Discussion Paper Series: Government and Competitiveness, School of Policy Studies, Queens University, 1994.

Craig, S.C. and McCann, J.M., “Assessing Communications Effects on Energy Conservation”, Journal of Consumer Research, 5 (September 1979), 82-88.

Dickson, P., Marketing Management, Fort Worth: The Dryden Press, 1994.

Drucker, P.F., "Managing the Public Service Institution,” The Public Interest, 33(1973), 43-60.

Drucker, P.F., What Business Can Learn from Nonprofits," Harvard Business Review, 67(July-August, 1989), 88-93. 
Fennell, G., "Persuasion as Behavioral Science in Business and Non-business Contexts," Advances in NonProfit Marketing, Vol.1, R.W. Belk (ed.), Greenwich, Conn: JAI Press, 1985, 95-160.

Kotler, P. And Turner, R.E., Marketing Management, Canadian 8th edition, Toronto: Prentice-Hall, 1995.

Kotler, P. and Andreasen, A., Strategic Marketing for Non-Profit Organizations, Upper Saddle, NJ:

Prentice-Hall, 1996.

Lipman, J., "When its Commercial Time, TV Viewers Prefer Cartoons to Celebrities Any Day," The Wall Street Journal, Feb. 16, 1990, B1, B4.

McLeish, B.L., Successful Strategies for Non-Profit Organizations, New York: John Wiley and Sons, 1995.

Naisbitt, J. and Aburdene, P., Megatrends 2000, New York: Avon Books, 1990

Novelli, W.D., "Social Issues and Direct Marketing: What's the Connection?," presentation to the Annual Conference of the Direct Mail/Marketing Association, Los Angeles, California, March 12, 1981.

Ogilvy D. and Raphaelson, J., "Research on Advertising Techniques that Work and Don't Work," Harvard Business Review, 60(July-August, 1982), 14-18.

Ottesen, O., The Response Function", Current Theories in Scandinavian Mass Communications Research, M.Berg (ed.) Grenaa, Denmark: GMT, 1977.

Rein, I., Kotler, P. and Stoller, M., High Visibility: How Executives, Politicians, Entertainers, Athletes and Other Professionals Create, Market and Achieve Successful Images, New York: Dodd, Mead, 1987.

Rice, F., "What Intelligent Consumers Want?,” Fortune, Dec. 28., 1992, 57

Rothschild, M., "Marketing Communications in Non-business Situations or Why it's So Hard to Sell Brotherhood like Soap," Journal of Marketing, 43(1979), 11-20.

Rothschild, M., Marketing Communications, Lexington: D.C. Heath \& Co., 1987.

Smith, D.H., "Determinants of Voluntary Association Participation and Volunteering: A Literature Review," Nonprofit and Voluntary Sector Quarterly, 23 (Fall 1993), 243-263.

Sterntha1, B., Dholakia, R.R. and Levitt, C., "The Persuasive Effect of Source Credibility: Test of Cognitive Response," Journal of Consumer Research, 4 (1978), 242-250.

Wilson, A., Practice Development for Professional Firms, Maidenhead: McGraw-Hill, 1984. 